\title{
Teacher-entrepreneurialism: a case of teacher identity formation in neoliberalizing education space in contemporary India
}

This article examines the processes underlying the formation of the identity of teachers as entrepreneurs in neoliberalizing education landscape in contemporary India. Drawing on interactions with 38 schoolteachers at two private schools in Dehradun, this article explores why and how educators adopt specific entrepreneurial strategies to navigate precarious, competitive market conditions. It subsequently illustrates how, in their pursuit of career advancement, educators commodify their knowledge and skills and promote the market logic of choice and freedom. By elucidating the mechanisms through which educators reproduce the processes and practices that nudge their search for promising career opportunities in the formal education system and the tuition industry, this article argues that teacher-entrepreneurs are both products and carriers of the neoliberal agenda. It introduces the concept of teacherentrepreneurialism, a manifestation of neoliberalism, which shapes educators' entrepreneurial dispositions; it suggests that teacher-entrepreneurs sustain neoliberalization in its varying forms and bolster its legitimacy. By illustrating the variegated, processual existence of neoliberalism, this article makes a case for investigating education as a neoliberalizing space in the increasingly profitcentric, market-driven, and performance-oriented schooling sector that prevails across societies, particularly in contemporary India.

Keywords: Teacher-entrepreneurialism, Neoliberalization, Teacher identity formation, Private schools, Tuition industry, Contemporary India

\section{Introduction}

Neoliberalism—defined variously, as a political-economic agenda, an ideological standpoint, a form of governmentality, and a hegemonic process — has been systemically transforming contemporary societies (Peck, 2010). As a ubiquitous and variegated process (Brenner, Peck, \& Theodore, 2010), neoliberalism shapes how individuals perceive and experience, "interpret, live in, and understand the world" (Harvey, 2007, p.3). In the education sector, 
neoliberal influences are characterised by privatisation, adoption of standardised curricula and specified pedagogical approaches, and provision of regular testing (Klees, 2008). These processes have effectively commodified educational resources and de-professionalised teachers' work (Macpherson, Robertson, \& Walford, 2014; Connell, 2013). Educators are expected to conform to prescribed performance criteria, and the narrowing of the curriculum and constraints on their pedagogical choices limit their autonomy in the classroom (Sachs, 2001). As such, the teaching profession has been reduced to "one that is both technicist and rote" (de Saxe, Bucknovitz, \& Mahoney-Mosedale, 2018, p.2).

Changing work conditions are inviting a variety of responses from educators. In some cases, schoolteachers are exercising their agency against the prescribed pedagogical framework (see MacDonald-Vemic \& Portelli, 2018; Ball \& Olmedo, 2013) and promoting social justice through their teaching performance in the classroom (MacDonald-Vemic \& Portelli, 2018). In other contexts, teachers are navigating the education market by adopting new practices, such as offering after-school paid tutoring support (see Dawson, 2009; Zhang \& Bray, 2017; Kobakhidze, 2018). These studies show the value of investigating teachers' response to structural transformation for producing a nuanced understanding of the shifting nature of the role, work, practices, and identity of a professional educator.

This article contributes to the ongoing debate on structurally produced professional identity by bringing into sharp focus the role neoliberalism plays in shaping the identity of teachers as entrepreneurs in contemporary India. It privileges the voices of 38 private school educators from Dehradun city in northern India. By drawing on "neoliberalization"- - that is, "both an 'out there' and 'in here' phenomenon whose effects are necessarily variegated and uneven" (Peck \& Tickell, 2002, p.383)—as a dominant conceptual framework, the article signifies the emergence of teacher-entrepreneurialism - an educator disposition that is shaped and nurtured by neoliberal ideals, processes, and effects in the education sector. 
Subsequently, it suggests that teachers' entrepreneurial approaches to managing their career illustrate the manifestation of neoliberal identity formation. By arguing that, as teacherentrepreneurs, educators are both products and carriers of the neoliberal agenda in the contemporary Indian schooling landscape, the article makes a case for investigating education as a neoliberalizing space in the increasingly profit-centric, market-driven, and performanceoriented schooling sector that prevails across societies, particularly in contemporary India.

In what follows, I first outline the scholarly discussion on teacher identity formation amidst neoliberalizing processes. Then, I will describe the empirical case of Indian schooling system and the methodological considerations underlying this study, before discussing how schoolteachers experience and perceive the education market and the strategies they adopt to navigate it. I then illustrate how, in the pursuit of career advancement, schoolteachers reproduce the structural conditions that inform their market strategies, and conclude the article with underscoring the importance of examining neoliberalism with(in) education.

\section{Teacher identity in neoliberalizing education sector}

Teacher identity, the process of becoming an educator, offers teachers a framework "to construct their own ideas of 'how to be', 'how to act' and 'how to understand' their work and their place in society" (Sachs, 2005, p.15). It is a dynamic and ever-evolving process that is multifaceted and multi-layered. For example: a variety of factors, as Oslen (2008) aptly captures here, play critical role in shaping educators' professional identity.

I view identity as a label, really, for the collection of influences and effects from immediate contexts, prior constructs of self, social positioning, and meaning systems (each itself a fluid influence and all together an ever-changing construct) that become intertwined inside the flow of activity as a teacher simultaneously reacts to and negotiates given contexts and human relationships at given moments. (p.139)

Indeed, educators' personal understanding of their professional role is instrumental in producing teacher identity. This process has been appraised in various ways by scholars. For 
example, while exploring the professional identity formation of six preservice teachers in the United States, Alsup (2006) finds the process "difficult, messy, and complex" (p.5) and suggests that it involves "'borderland discourse'-discourse in which there is evidence of integration or negotiation of personal and professional selves" (p.xiii). Appreciating its various dimensions, Akkerman and Meijer (2011) propose a dialogical approach to explain "both unitary and multiple, both continuous and discontinuous, and both individual and social" aspects of teacher identity (p.309).

Moreover, identity shifts and reconfigures under transforming structural conditions. For example, Sachs (2001) argues that teachers shift between a structurally imposed managerial identity and democratic identity that stems from their professional practices in the Australian context. Importantly, Zembylas (2003) makes a case for exploring "emotions" as "sites of resistance and self-transformation" (p.214) to comprehend the "teacher-self" that is "becoming in a context embedded in power relations, ideology, and culture" (p.233). Teacher identity also tends to (re)formulate in interactions with structural demands that make specific ways of teaching obligatory and in response to the constraints that structures impose on educators' professional selves (for discussion, see Beauchamp \& Thomas, 2009).

Many studies emphasise how neoliberal policies operate as a powerful reform apparatus that has fundamentally transformed the education system and led to the reformation of educators' professional subjectivity.

$[\mathrm{P}]$ olicy technologies of education reform are not simply vehicles for the technical and structural change of organizations but are also mechanisms for reforming teachers (scholars and researchers) and for changing what it means to be a teacher, the technologies of reform produce new kinds of teacher subjects. (Ball, 2003, p.217)

Writing from an Australian perspective but with wider significance, Connell (2013) observes that the market agenda that results in "rationing education" produces an "insecure workforce", leading teachers to "narrow their efforts, to focus on what is testable", thereby 
undermining "teachers' capacity to develop curricula appropriate to their actual pupils" (p.107). Amidst this tussle between "short-term results and long-term effects", Connell (2013) argues, "a rhetoric of teacher professionalism contradicts the emerging industrial and technical realities of teachers' work" (p.108).

Ball and Olmedo (2013) approach educators' perspectives on structural conditions from a Foucauldian lens. In their study, based on email interactions with educators, they find that teachers perform "irresponsibly" to resist neoliberal reform and, thus, they "take 'responsibility' for the care of their selves” (p.85). In another study, Moore and Clarke (2016) propose that teachers adopt "reworked discourses of organisational professionalism" to facilitate their "enactment of the demands that neoliberal capitalism makes on education", therefore, the authors argue, "[t]hese discourses...secure allegiance through teachers' desire for recognition and approval” (p.675).

Overall, neoliberal forces shape in important ways "the horizon of possibilities and practices through which the subject actively constitutes him/herself” within socioeconomic and epistemological contexts (Ball \& Olmedo, 2013, p.87). Conceptually embedded in the scholarship of teacher identity formation in "neoliberalizing" educational space (Peck \& Tickell, 2002), this article contributes to ongoing discussion by showing that teacher identity is mediated through educators' wide-ranging experiences and realised gradually in their responses to systemic and structural neoliberal processes in the empirical context. I use neoliberalization (Peck \& Tickell, 2002) as a conceptual framework because it renders neoliberalism, an otherwise "inconsistently defined, empirically imprecise and frequently contested" phenomenon, more accessible (Brenner, Peck, \& Theodore, 2010, p.182).

As a variegated analytical concept, neoliberalization contradicts the notion that substantiates homogenisation of regulatory systems and practices and "usefully draws attention to the contextually embedded character of market-oriented forms of regulatory 
restructuring" (ibid, p.201). I examine structurally produced teaching practices in an attempt to explicate the formation of the identity of educators as entrepreneurs, thereby emphasising the role of neoliberal forces in continuously (re)configuring the landscape of education delivery in contemporary India.

\section{Indian schooling landscape-an overview}

The gross enrolment ratio at elementary schools (classes I to VIII) in India rose from $32 \%$ to 68\% between 1950 and 1980; and then to 100\% in 2007 (NUEPA, 2014). This steep increase in school enrolment coincided with the IMF-envisioned Structural Adjustment Programme that the Indian state adopted in 1991. Recognising that education is "the most crucial investment in human development", the ninth Five-Year Plan (1997-2007) listed the universalisation of primary education as a state priority. Despite being reviewed critically (see Kumar, Priyam, \& Saxena, 2001; Kumar, 2019), government-led and supported initiatives adopted immediately before, during, and after this Plan—such as the 1993 District Primary Education Programme, the 2000 Education for All movement, and the 2009 Right to Education Act (RTE)—are enshrined in the state's narrative as key contributors in widening educational participation.

Motivated by the neoliberal agenda for economic growth, education development in the past three decades has engendered rampant growth in the private sector's involvement in education delivery. The Indian state, as noted below, has commended and promoted the private sector's role in attaining "education for all":

Their [the private sector's] legitimate role in expanding elementary education needs to be recognised, and a flexible approach needs to be adopted to encourage them to invest in the sector. The current licensing and regulatory restrictions in the sector could be eased, and a single window approach should be adopted so that the process of opening new schools by private providers is streamlined. (Planning Commission, 2013, p.64) 
The transfer of the state's responsibility for delivering education to the private sector effectively and systemically initiates "a process in which the state shifts the blame for the very evident inequalities in access and outcome it has promised to reduce, from itself onto individual schools, parents, and children" (Apple, 2001, p.416; see Velaskar, 2010; Jha, 2005). Interestingly, despite the free and incentivised provision for public schooling at elementary levels under RTE, parents are still choosing private schools for their children's education. This preference is attributable to perceived and, at times, actual potential of private schools to offer superior quality in educational resources (The Probe Team, 1999; James \& Woodhead, 2014). In 2014-15, 42.1\% and 20.8\% of school-going children aged 6-18 in urban and rural areas, respectively, attended unaided (without government support) private schools (Kingdon, 2017). Notably, private schools do not exclusively serve the elite social groups. Their fee structure varies significantly, enabling both middle-class and economically weaker families access to them (see, Gupta, 2019; Srivastava, 2013).

Privatisation in the Indian education system proliferates through not only the growth of and increasing enrolment in private schools but also due to the pervasiveness and increasing popularity of 'shadow' education businesses. The 2015 Annual Social Consumption Report notes that nearly $26 \%$ (around 71 million) of students seek tutoring support at various educational levels (Government of India, 2015). It is a common belief among parents that "private tuition is 'unavoidable' if it can be at all afforded" (Sen, 2009, p.13; also see, Bhorkar \& Bray, 2018). Parents from economically better-off families, who are more likely to enrol their children into private schools, invest in additional tutoring support to provide their children with a competitive edge (Majumdar, 2018). By contrast, economically weaker families, who are relatively less likely than their middle-class counterparts to invest in tutoring support (see Azam, 2016), rely on tutoring support, 
presumably to compensate for the perceived poor quality of public education (Wadhwa, 2013).

The interaction between formal schools and tutoring provisions is further complicated when schoolteachers assume tutoring roles. Despite the lack of systematic research on the topic, anecdotal evidence suggests that teachers deprive their students of access to educational resources in classrooms, thereby forcing them to solicit extra-school academic support from them (Biswal, 1999). Students comply with their teachers' demands out of fear of being discriminated against in the classroom and unfairly assessed (Sujatha, 2014). Recognising the implications of this practice for the quality of formal schooling, the Indian state has prohibited teachers from engaging in "private tuition or private teaching activity" (Government of India, 2009). While the state's stance on private tutoring creates apprehension among schoolteachers, their involvement in the tuition industry remains prominent (Sujatha, 2014; Majumdar, 2018).

Overall, the Indian education sector is increasingly undergoing privatisation, and, although private education in itself may not necessarily guarantee the desired educational advantages (see, Gupta, 2019; Srivastava, 2013), the wider implications this process has for educational practices are yet to be fully exposed and critically discussed. This article redresses this gap by exploring schoolteachers' perspectives on the impact of neoliberalism on their professional experiences and investigates the role these processes play in shaping teacher identity. In doing so, the article offers useful insights into how education is perceived, delivered, and commodified within increasingly transforming education market in contemporary India.

\section{Methodological considerations}

This article draws on a crucial part of a more extensive "institutional ethnography" (Smith, 2005) that explored educational practices in formal educational institutions from the vantage 
point of private tutoring between December 2014 and December 2015 in Dehradun, the capital city of the state of Uttarakhand in northern India. This article focuses primarily on my interactions with 38 schoolteachers engaged in teaching students at the secondary education level (class IX to XII) at two private schools (pseudonymised), Himalayan International School (HIS) (15 schoolteachers) and Sharda Secondary School (SSS) (23 schoolteachers). Founded in 2004, HIS had 562 students enrolled and 30 teachers employed in 201415. The annual school fees ranged from INR 55,000 to INR 78,000 (equivalent to USD 863 to USD 1,224) from class VI to class XII. SSS was founded in the 1970s. It housed 786 students and 41 teachers at the time of the fieldwork and charged annual fees varying between INR 40,000 and INR 55,000 (equivalent to USD 628 to USD 785) from class VI to class XII. Teachers' monthly salaries in both schools ranged from INR 10,000 (equivalent to USD 156) to INR 40,000 (equivalent to USD 632). By comparison, public schools charge no fees at the elementary educational level and nominal fees at the secondary level. In these schools, teachers' monthly pay starts at INR 35,000 (equivalent to USD 553) and rises with teaching experience.

Drawing on Smith's (2005) approach to conducting a sociological inquiry, the fieldwork aimed to explore the aspects of the educational institution that are "relevant" to educators' experiences (p.38). In data production and analysis, I necessarily privilege educators' standpoints to reveal how their experiences "are situated in their relationships to an institutional order" (p.32). In doing so, I hope to offer a scholarly assessment of "how our everyday lives participate in and are embedded in relations that aren't visible from within them" (p.38). These relations were exposed, explicated, and articulated by educators during our conversations about the education system, its processes and practices, and market conditions. 
I initially interviewed all educators individually. In these introductory conversations, which typically lasted from 1 to 1.5 hours, schoolteachers shared their life stories and their views on their immediate education context. In-depth discussions mostly occurred informally - in corridors, over luncheons, and when overseeing school events and sports activities - during the 1-year period of fieldwork. These opportunistic interactions offered me the space and scope to engage with teachers' thought processes in a more nuanced way (see Smith, 2005) and helped to generate more detailed, intricate, complex, challenging, and thought-provoking narrations of educators' relationships with the schooling sector.

I transcribed both the interviews and the informal conversations and conducted the analysis by first segmenting and then reassembling the material (Boeije, 2010). I segmented the material by coding the transcripts, which led to breaking up parts of the conversations into specific codes. I reassembled the codes to understand the patterns and identify the themes that emerged from the data. Thematic patterns that are relevant to this article are presented in the next section.

\section{Teachers as entrepreneurs—-products and carriers of the neoliberal agenda}

This section discusses the processes underlying the formation of teacher-entrepreneurs across four themes - educators' views on privatising the education sector, their approaches to navigating the education market, the neoliberal rationality of teacher-entrepreneurs, and educators' role in legitimising the tuition industry — that explore schoolteachers' relationship with the neoliberalizing schooling sector. In doing so, it illustrates how teachers both respond to and contribute to the neoliberal impulses driving education in contemporary India.

\section{Educators' perceptions and experiences of privatising the schooling sector}

Schoolteachers typically described their immediate education market as "evolving", "full of promise", and "desirable for skilled professionals". At the same time, they felt it was "unpredictable", "uncertain”, and "stressful”. This dichotomy in participants' narrations is 
illustrated in the following excerpt from my interview with Ajay, a teacher at HIS:

Like many of us [teachers], I came here [to Dehradun from Pauri, a hilly district in Uttarakhand] to live a city life and find a better job...Dehradun is an education hub. There must be hundreds of schools here. However, it is the same story everywhere. You are hired on a temporary basis. Usually, you have to work beyond typical schooling hours, and the management cuts my salary for each day I am on leave. So, it [the teaching job] can be very stressful. At the same time, there is no room for complaint. Many people are waiting to get your job. This is how the private sector works, after all.

As shown here, participants viewed the expansion of the education sector as promising for advancing their career prospects. As member of upper-caste and middle-class families, these educators had sufficient financial resources and social connections that enabled them to migrate from relatively less infrastructurally developed hilly regions to Dehradun to fulfil their aspirations. They associated a variety of social and spatial advantages of "living in a modern city", particularly for "providing their children with the best education" (see Gupta, 2019 for the discussion). Simultaneously, though, these schoolteachers felt vulnerable while operating within a precarious, competitive, insecure, and stressful work regime.

While they embraced their work conditions as typical experiences in the privatised education market, as Ajay mentions, the educators expressed their disappointment when comparing their experiences to those of their counterparts in public schools.

Your life is pretty much settled if you work in a government school. You enjoy a high salary, a permanent job, and additional benefits, such as medical leave and a pension scheme. Conversely, we do not even have a secure job (in the private sector), we earn so much less in comparison and have virtually no benefits. (Himani, SSS teacher)

Indeed, work conditions for educators in public schools are substantially different from those who are employed by private schools (such as HIS and SSS) that are neither elite nor low-fee. For example, as government employees, schoolteachers in the public sector 
receive a steady rise in their salary as per state regulations. By contrast, profit-driven private schools tend to charge high fees but offer low salaries to their employees to optimise their financial resources, as exemplified in the pay discrepancy mentioned previously under methodological considerations in this article. These aspects are crucial part of strategic and pervasive privatisation of public schooling in India (see, Ball, 2012).

Even though they were paid less, these schoolteachers believed that they perform better than most public schoolteachers. They spoke of being provided with a prescribed set of tasks, which the school managers believed teachers were required to accomplish "timely", "meticulously", and "efficiently" to be assessed positively on measures of accountability and performance. The director of HIS makes the following remark on teachers' work:

We are a school of some standing. No-one in this block [of housing] would send their children to any other school in town. We keep checks on our teachers...it's their job, and they are paid for it. This is not a government school, where teachers do nothing. We have a structure that guides teachers to do their job properly. The same structure provides us with a framework to assess their performance regularly. If they are busy, it means we are doing something right.

School management at both schools frequently mentioned that "holding teachers accountable" is a crucial driver for ensuring popularity of their school in the increasingly competitive, marketized, and privatised education market. Teachers listed a range of responsibilities_-including but not limited to "recording children's attendance", "liaising with school administration and parents to ensure that the important bills and other dues are paid", "completing syllabi timely", "organising and executing regular assessments", “producing report cards", "delivering grades within 2 weeks of each assessment", "preparing a personal assessment file for each student", and "preparing for regular parent-teacher meetings"- that they were required to perform as schoolteachers. 
School management monitored educators' activities and used a surveillance system to ensure that teachers are held accountable. This form of governing, however, had severe implications for the educators' academic efficacy in the classroom, exemplified here in my conversation with Sujatha, a biology teacher at HIS:

I perform my job meticulously. However, honestly, we barely have time to actually teach. We [teachers] all rush to finish the syllabus towards the end of the academic year. It is impossible to ensure that every child in the classroom learns all the concepts of one chapter in merely $35-40$ minutes...I do provide some notes for exam preparation, but I also understand that they might not be sufficient.

These neoliberal processes of unpredictable market conditions, prescribed curriculum and pedagogical practices, and surveillance of teachers' work in the privatised education sector seldom allow educators the opportunity to use pedagogical approaches that they believe will foster effective learning. Amidst these processes, educators often spoke of finding their work at school both "inauthentic and alienating" (Ball, 2012, p.32; see Macpherson, Robertson, \& Walford, 2014). Moreover, they felt that these structural processes systematically produce teaching and learning deficits in the classroom. While recognising the problematic effects of neoliberalization in the education sector, participants adhered to the schooling practices because they lacked agency to resist the system from within and resolved to navigate the education market more entrepreneurially.

\section{Educators' approaches to navigating the precarious market conditions}

Experiences of the precarity and de-professionalisation of their role in schools, as shown above, nudge educators' search for better employment opportunities in the increasingly privatising and marketizing schooling sector. When speaking of the need to seek and seize career opportunities in the wider education market, schoolteachers reflected on how traditional perceptions of schools as Mandirs (temples) or sacred places, and teachers as Gurus were redundant in the system where education is openly bought and sold-a system 
that promotes cut-throat competition and runs on performance ratings.

Himani (HIS teacher), for example, said, that "in situations where management tells you what to do, schools are no different from corporations". Discernibly disenchanted with the idea that "education is a public good", participants viewed schools as "enterprises" with "business-like functioning" and saw themselves as "valuable resources" that the school management requires for meeting their profit-making objectives.

Schools are like businesses. They are always on the lookout for a qualified teacher with wide-ranging experience. I have 5 years of teaching experience, and I would not hesitate to leave a job to find another if it paid better. I joined HIS two years ago because they offered a better salary package than I had at my previous school. Many of my colleagues have moved to other newly established private schools because the pay is higher. (Ajay, HIS teacher)

Participants spoke of their subject knowledge and skills as assets whose value they monetise and negotiate at competitive market rate. The arena of such negotiation expanded for most schoolteachers I spoke with from formal schooling to private tutoring. Participants, especially those with expertise in popular, mostly science-based, subjects, actively supplied private tutoring aid in varying capacities and earned significantly in exchange for their educational services. For example:

I run my own centre and offer five physics sessions each day to class XI and XII students. From 40 tutees each, I earn INR 1,000 per month (total income: approximately USD 640 per month), which is about double the salary I receive for my full-time job as a schoolteacher. (Himanshu, SSS teacher)

I run course review and mock test sessions for 3 months in a coaching centre. These are for students sitting Board Examinations [high-stakes examinations at class $\mathrm{X}$ and class XII levels]. Just before the final exams, students flock to attend crash courses (quick revision and practice sessions) offered by tutorial centres. You have to give 20-25\% of your earnings to the centre, but still you can earn a lot of money. For example, last year, I 
earned INR 60,000 (equivalent to USD 867) for teaching 40 students. It's becoming popular among young teachers. (Arvind, HIS teacher)

While some teachers spoke of preferring the "autonomy" and "convenience" of running their own centre, others sought partnership with other full-time or part-time tutors for “shared responsibility". For example, Aakash provided mathematics tutorials to class IX-X students in a centre where different tutors offered sessions for other subjects and educational levels. Meanwhile, teachers like Arvind found "short-term" or "seasonal" tutoring arrangements more fitting. Overall, the educators were proactive and strategic in their career approaches and spoke of concertedly cultivating their academic capital to elevate their "market value" in both formal schooling and tutoring businesses.

Importantly, with an entrepreneurial stance and being "masters of their own destiny", the schoolteachers felt that instead of being controlled and constrained by the neoliberal regime in the formal schooling system, they were effectively exploiting the market conditions to their advantage. In doing so, educators viewed themselves "as individuals who calculate about themselves, 'add value' to themselves, improve their productivity, strive for excellence and live an existence of calculation" (Ball, 2003, p.217).

Moreover, aligning with Sachs's (2005) observation that identity of a teacher is seldom "imposed; rather it is negotiated through experience and the sense that is made of that experience" (p.15), this section shows that the identity of teachers as entrepreneurs emerges in educators' reflections on their work conditions, market dynamics, and navigational strategies in response to neoliberalizing forces. Importantly, as competitive and performancedriven managers of their careers, teacher-entrepreneurs were effectively commodifying the public profession (Ball, 2012), and consequently intensifying the effects of neoliberalizing forces in the schooling sector. 


\section{Neoliberal rationality of teacher-entrepreneurs under market rule}

Educators' stance as entrepreneurs and neoliberal subjects surfaced in their narratives of the professional identity of a schoolteacher in the privatised education sector. Here, for example, Ajay (SSS teacher) typifies the reflection of most educators on what it means to be a schoolteacher in a market-driven schooling system.

As a teacher, I consider myself a trained professional. We have the right to chase opportunities however we want. I mean, why shouldn't we? After all, teaching is a profession, like banking. It is typical for people to move to different organisations to advance their careers. So why should teachers be seen differently?

It was common for the educators to compare teaching to other professional jobs to explain how they viewed the nature and scope of their professional role. As shown above, teachers felt that their role was not restricted to be a schoolteacher, rather it expanded onto shadow education businesses. When justifying their action to seize tutoring opportunities for gainful employment, teachers often emphasised that they are "chosen" by their financially well-off clients in an open and fair competition with other tutors.

I did not set out to run my centre. It was the parents who live in the same residential complex as me who asked if I could tutor their kids. There are plenty of tutors in the market and parents could have gone to any of them, but they chose me. I know that they can easily afford the tutoring costs. (Rekha, HIS teacher)

Even though participants felt that it was "fair" for them to offer tutoring support to clients who are "free to choose" from the available tutoring services, they tended to articulate the nature of their tutoring role cautiously. Some participants would openly distance themselves from schoolteachers who treat schools as their market site. These teachers, in the participants' view, impose their tutorial classes on students either coercively or covertly through favouritism (see, for example, Zhang, 2014; Bray, Kobakhidze, Liu, \& Zhang, 2016). 
In fact, quite a few participants spoke against forcing students to attend tutoring sessions with them.

I do not think it is right to force children to [attend your own tutorial classes to] advance one's career. There may be a few teachers who do that, but I condemn it. I have even said 'no' to my students from school who wanted to join my tutorial lessons. It is just not right, you know. [Informal conversation with Mahima, HIS teacher]

Indeed, the participants often stressed their "rightful approach" to straddling the formal and shadow education systems, and characterised certain practices as "wrong" and "unethical". These moral judgements were admittedly informed by the institutional regulations of school management and the 2009 Right to Education Act that actively discourage teachers from partaking in the tuition industry to avoid the possibility of corruption. While the scope of neoliberal rationality in pursuing entrepreneurial goals was requisitely evaluated and negotiated by schoolteachers, this logic still prevailed in situations that were otherwise problematised by the educators themselves in very few interactions I had with schoolteachers. For example:

Technically, teachers are the most suitable tutors. They know their students well and can probably guide them more effectively than anybody else. It is not like the child would not go for tuition [classes] elsewhere if a teacher did not offer paid lessons. What I am saying is that "technically" it is not such a bad idea today when everyone seeks tuition [support], parents are willing to pay for the additional academic support and teachers have the expertise to offer it. It is really a win-win situation. [informal chat with Suresh, SSS teacher]

Suresh's words underscore "the significance of contractual relations in the marketplace" and belief that "the social good will be maximised by maximising the reach and frequency of market transactions" (Harvey, 2007, p.3). This quotation also draws connections between the structural factors of middle-class aspirations and credentialism, resulting in the perceived necessity and consequent pervasiveness of tutoring provisions in the Indian 
education landscape (Gupta, 2019; Ghosh \& Bray, 2018) and the practices of teacherentrepreneurs in supplying valuable resources through selling their expertise. The discussion presented here also shows that educators' disposition as teacher-entrepreneurs is not only informed by but also nurtured by privatising and marketizing processes.

\section{The role of teacher-tutors in legitimizing the tuition industry}

While schoolteachers repeatedly stated that their dual roles as teachers in school and tutors in tutorial centres are mutually exclusive, in practice, they were intricately intertwined and presented several implications for market dynamics in the schooling sector. For example, when responding to the query of what strategies educators employed to marketize their tutoring services, in addition to foregrounding their educational qualifications and touting the academic performance of their former tutees to prove their credentials, educators felt that they had added advantage due to their affiliation with a school. Participants believed that their identity as schoolteachers fostered the social perception of them as "reliable" tutors. Also, as shown below, affiliation with a popular school not just validates but also leverages schoolteachers' position in the tuition market.

As a qualified teacher, I do not have to prove I am the right candidate for my tutoring role...I realise that many students might be interested in having tutoring sessions with me because I teach at SSS. Most of my tutees have tried to enrol in SSS, but the admission criteria are quite stringent. By signing up for tuition classes with me, maybe the parents think their children will get the quality education that SSS is known for offering.

(Aakash, SSS teacher)

Few teachers at SSS spoke about not quitting their full-time job or switching to another school for income benefits because they believed their affiliation with a popular school had provided them with greater opportunities in the tutoring market. Thus, teachers were proactively balancing their tutorial and teaching roles to gain positional advantage in the brand-valuing education sector. 
Moreover, as "insiders to the system", educators acknowledged that they had invaluable "experiential knowledge of the inner workings of the education system"- the curriculum, assessment patterns, and evaluation schemes - which they marketized and admittedly exploited to offer their tutees adequate resources to excel in the school appraisal system. Notable here is the difference between how participants spoke of their duties as tutors and how they articulated their role as schoolteachers.

I design [tutoring] sessions not just to complete the syllabus but also in alignment with what I think students need to perform well in assessments. I introduce concepts and use different examples to communicate the concepts, often repeating them until students have a sufficient grasp of them. (Sujatha, a biology teacher at HIS)

What Sujatha's views on her role as a teacher (mentioned earlier) and tutor (above) show is the differential in educators' commitment to attain academic efficacy in the two settings. Indeed, while educators assertively disassociate themselves from their students' academic failure in schools (see Gupta, 2019), they feel entirely responsible for their tutees' grades. Moreover, all the educators, some hesitantly and others more assertively, admitted that, even though it is "unintentional", they teach "more effectively" in tutorial centres than they do in school. These factors, coupled with the small class size — approximately 10 students in tutorial sessions, compared to 40 students in a school classroom - and the amount and nature of tasks educators perform in these educational settings, perceivably enhance schoolteachers' academic efficacy and their overall performance in tutorial centres. Notably, some teachers also mentioned that they as tutors "make up for the teaching deficits" that are inevitably created (discussed earlier) in formal educational institutions.

Teachers often attributed the perceived differential in their performance to experiencing "freedom" and "autonomy" in the tutoring sector (see Kobakhidze, 2018) and feeling restricted, limited, and reduced in their teaching role in schools (see Connell, 2013; 
Sachs, 2001). Also, there were other aspects of the institutional arrangement of the shadow education system that had shaped educators' approach to teaching in tutorial settings.

The [tutoring] market is very unpredictable. I cannot always control the number of students who might be willing to attend [my tutorial] sessions. Even if they come regularly, they are free to leave at any point. It is their choice. I need to prove continually that I am an excellent teacher to stay relevant in the market. (Aarti, HIS teacher)

Therefore, educators' utterances of immaculately designing study plans and fostering students' interest in the subject were often intertwined with their noticeable fear of being perceived as incapable of meeting demands in the tutoring industry and not surviving the extremely competitive market conditions that feed on the quantified measures of individuals' success.

Notably, neoliberalism operates differently in schools than it does in the tuition industry. Consequently, it shapes teachers' perceptions and experiences of their professional work corresponding to these settings. That is, due to the variety in structurally imposed measures to evaluate schoolteachers' performance and the distinctive conceptualisation of assessing educators' accountability in formal schooling and the tuition industry, the same educator who feels unable to perform their teaching duties well in school may find themselves excelling in their teaching role in a tutorial set-up. This perceived differential in educators' practices, stemming from their response to the organisational arrangement of formal and shadow education systems, legitimises the relevance and effectiveness of tutoring businesses. By extension, such perceptions intensify neoliberal impulses and amplify their implications for the wider education landscape.

\section{Conclusion}

This article has explored how neoliberal processes shape the way educators perceive, experience, and perform their professional roles and responsibilities and how, in doing so, 
they realise and promote formation of the identity of teachers as entrepreneurs in contemporary India. In an attempt to capture neoliberalization in its "moments of actualisation, failure, normalisation, and adaptation" (Peck, 2010, p.33), the article shows the mechanisms through which structural conditions shape the construction of teacherentrepreneurs as neoliberal subjects, who, through their rationality and educational practices, reproduce neoliberalism in its varying forms, sustain its claims, and bolster its legitimacy. This article therefore maintains that schoolteachers are both products and carriers of the neoliberal agenda and that neoliberalism exists in its variegated forms around, within, and through teacher-entrepreneurs.

I argue that formation of the identity of teachers as entrepreneurs is a manifestation of neoliberal influences on the education sector. The current market regime creates uncertain, insecure working conditions for educators and often leaves them feeling vulnerable (noted in Connell, 2013; Sachs, 2001). In response, teachers concertedly cultivate their professional careers by strategically seeking and seizing promising and monetarily beneficial job opportunities within the wider education market. In doing so, educators perceive limiting the scope of their work to schools as reductive and unfair, and advocate for schoolteachers to pursue tutoring opportunities, which expand the offerings of the privatised education market. The working conditions in the formal schooling system that enforce educators' entrepreneurial disposition and shape their decision-making process, such as becoming tutors to navigate the competitive and precarious market, are "embedded within wider networks and structures of neoliberalism” (Peck \& Tickell, 2002, p.380).

This article also catches glimpses of neoliberalism in its "variegated forms" (Peck, 2010), resulting in self-perceived variety in educators' academic performance in schools and tutorial centres. Educators recognise the overall uncertainly and unpredictability of their careers. However, their experiences vary significantly in schools and tutoring settings. In 
schools, they seldom feel free to use their resourcefulness to facilitate classroom learning. Conversely, market-driven forces in the tuition industry offer educators a sense of freedom and autonomy, which motivates them to realise their full academic potential and even compensate for perceived teaching deficits in schools.

Rooted within the neoliberal agenda, teacher-entrepreneurialism enforces, promotes, and nourishes market regulations in the education domain. This article demonstrates how, as neoliberal agents, teacher-entrepreneurs commodify their valuable knowledge and skills to capitalise on market competition between schools and institutionally generated demand for private learning support. In doing so, they intensify the processes of privatisation and marketisation and strengthen the neoliberal regime that fosters competitiveness, promotes quantifiable performance, and favours accountability measures. Moreover, through their actions, educators reinforce the perceived necessity of tutoring support alongside schools, legitimising the role of tutorial centres in the landscape of education delivery and thereby undermining the imperative to attain educational equality. Thus, while operating in "systematic connection with neoliberalization as a macro process" (Peck \& Tickell, 2002, p.396), teacher-entrepreneurs, by actively "rationing" education (Connell, 2013), (re)produce conditions conducive to the expansion of the "political project" of neoliberalism, which is "to re-establish the conditions for capital accumulation and to restore the power of economic elites" (Harvey, 2007, p.19).

By providing a nuanced understanding of how structural changes generate specific education practices, produce teacher-entrepreneurs, and discussing the possible implications of these changes, this article offers useful insights into the often-underestimated transformative capacity of neoliberalism. It shows that teacher identity is discursively produced from educators' approach to adjusting with structural changes and realised gradually in teachers' reflective, reflexive, responsive and creative practices. Thus, the article 
acknowledges the importance of discourse (Alsup, 2006) and dialogical approaches to explain teacher identity (Akkerman \& Meijer, 2011) and emphasises the imperative to generate nuanced accounts of educators' narratives to understand the responsive effects of contextually embedded structurally-contingent educational practices on influencing and shaping educators' understanding of their professional role and identity.

Generating such an understanding is instrumental for investigating the influence of often vaguely defined and inadequately explained, yet profoundly powerful and contextually specific and complex processes, such as neoliberalism. Further investigation on how these processes interact with social actors in varied institutional settings would elucidate the mechanisms through which new norms are established and belief systems are reconfigured in everyday society. Admittedly, this article draws on a small-scale study of 38 private schoolteachers in Dehradun. Educators in other settings, for example, in public schools, might exert different identities, or the same entrepreneurial identity differently, through their responsive educational practices. Identifying those similarities and differences is critical to fully understand the implications of structural processes for reconfiguring organisational arrangements and practices in the broader landscape of education delivery.

Finally, by revealing the processual existence of neoliberalism in how teacherentrepreneurs reproduce the regime that shapes their identity, this article makes a case for investigating schooling as a "neoliberalizing space" (Peck \& Tickell, 2002). In unveiling specific ways in which neoliberalism exerts its influence, this article suggests that it is imperative to examine underexplored and hidden aspects concerning neoliberalism in the education domain to reveal this process and its effects within and across societies more comprehensively.

\section{Disclosure statement}

The author declares no conflict of interest in relation to this paper. 


\section{References}

Akkerman, S. F., \& Meijer, P. C. (2011). A dialogical approach to conceptualizing teacher identity. Teaching and Teacher Education, 27(2), 308-319.

Alsup, J. (2006). Teacher identity discourses: Negotiating personal and professional spaces. New York, NY: Routledge.

Apple, M. W. (2001). Comparing neo-liberal projects and inequality in education. Comparative Education, 37(4), 409-423.

Azam, M. (2016). Private tutoring: Evidence from India. Review of Development Economics, 20(4), 739-761.

Ball, S. J. (2012). Global Education, Inc.: New policy networks and the neoliberal imaginary. New York, NY: Routledge.

Ball, S. J. (2003). The teacher's soul and the terrors of performativity. Journal of Education Policy, 18(2), 215-228.

Ball, S. J., \& Olmedo, A. (2013). Care of the self, resistance and subjectivity under neoliberal governmentalities. Critical Studies in Education, 54(1), 85-96.

Beauchamp, C., \& Thomas, L. (2009). Understanding teacher identity: An overview of issues in the literature and implications for teacher education. Cambridge Journal of Education, 39(2), 175-189.

Bhorkar, S., \& Bray, M. (2018). The expansion and roles of private tutoring in India: From supplementation to supplantation. International Journal of Educational Development, 62, 148-156.

Biswal, B. P. (1999). Private tutoring and public corruption: A cost-effective education system for developing countries. The Developing Economies, 37(2), 222-240. 
Boeije, H. (2010). Analysis in qualitative research. Los Angeles, CA: Sage.

Bray, M., Kobakhidze, M. N., Liu, J., \& Zhang, W. (2016). The internal dynamics of privatised public education: Fee-charging supplementary tutoring provided by teachers in Cambodia. International Journal of Educational Development, 49, 291299.

Brenner, N., Peck, J., \& Theodore, N. (2010). Variegated neoliberalization: Geographies, modalities, pathways. Global networks, 10(2), 182-222.

Connell, R. (2013). The neoliberal cascade and education: An essay on the market agenda and its consequences. Critical Studies in Education, 54(2), 99-112.

Dawson, W. (2009). The tricks of the teacher: Shadow education and corruption in Cambodia. In Heyneman, Stephen P. (Ed.), Buying your way into heaven: Education and corruption in international perspective (pp. 51-74). Rotterdam: Sense Publishers.

de Saxe, J. G., Bucknovitz, S., \& Mahoney-Mosedale, F. (2018). The Deprofessionalization of educators: An intersectional analysis of neoliberalism and education "reform". Education and Urban Society, 1.

Ghosh, P., \& Bray, M. (2018). Credentialism and demand for private supplementary tutoring: A comparative study of students following two examination boards in India. International Journal of Comparative Education and Development, 20(1), 33 50.

Government of India (2009). The right of children to free and compulsory education act. Retrieved from: http://www.education.nic.in/elementary/

Government of India (2015). Key indicators of social consumption in India: Education. New Delhi: Ministry of Statistics and Programme Implementation. 
Gupta, A. (2019). Heterogeneous middle-class and disparate educational advantage: Parental investment in their children's schooling in Dehradun, India. British Journal of Sociology of Education, 1-16.

Harvey, D. (2007). A brief history of neoliberalism. Oxford: Oxford University Press.

James, Z., \& Woodhead, M. (2014). Choosing and changing schools in India's private and government sectors: Young lives evidence from Andhra Pradesh. Oxford Review of Education, 40(1), 73-90.

Jha, P. (2005). Withering commitments and weakening progress: State and education in the era of neoliberal reforms. Economic and Political Weekly, 3677-3684.

Kingdon, G. G. (2017). The emptying of public schools and growth of private schools in India. Budget Private, 12.

Klees, S. J. (2008). A quarter century of neoliberal thinking in education: Misleading analyses and failed policies. Globalisation, Societies and Education, 6(4), 311-348.

Kobakhidze, M. N. (2018) Teachers as tutors: Shadow education market dynamics in Georgia. Dordrecht: Springer.

Kumar, K. (2019). Dilution of the Right to Education Act. Economic and Political Weekly, $\operatorname{LIV}(14), 14-15$.

Kumar, K., Priyam, M., \& Saxena, S. (2001). Looking beyond the smokescreen: DPEP and primary education in India. Economic and Political Weekly, 560-568.

MacDonald-Vemic, A., \& Portelli, J. (2018). Performance power: The impact of neoliberalism on social justice educators' ways of speaking about their educational practice. Critical Studies in Education. doi: 10.1080/17508487.2018.1428642 
Macpherson, I., Robertson, S., \& Walford, G. (Eds.). (2014). Education, privatisation and social justice: Case studies from Africa, South Asia and South East Asia. Oxford: Symposium Books, Ltd.

Majumdar, M. (2018). Access, success, and excess: Debating shadow education in India. In Kumar, K. (Ed.), Routledge Handbook on Education in India: Debates, Practices and Policies (pp. 273-284). New York, NY: Routledge.

Moore, A., \& Clarke, M. (2016). 'Cruel optimism': Teacher attachment to professionalism in an era of performativity. Journal of Education Policy, 31(5), 666-677.

NUEPA (2014). Education for all: Towards quality with equity. New Delhi: NUEPA. Retrieved from: http://mhrd.gov.in/sites/upload_files/mhrd/files/upload_document/EFA-ReviewReport-final.pdf.

Olsen, B. (2008). Teaching what they learn, learning what they live. Boulder, CO: Paradigm Publishers.

Peck, J. (2010). Constructions of neoliberal reason. Oxford: Oxford University Press.

Peck, J., \& Tickell, A. (2002). Neoliberalizing space. Antipode, 34(3), 380-404.

Planning Commission (Government of India) (2013). Twelfth Five Year Plan (2012-2017), Social Sectors, Volume III. New Delhi: Sage publications.

Sachs, J. (2001). Teacher professional identity: Competing discourses, competing outcomes. Journal of Education Policy, 16(2), 149-161.

Sachs, J. (2005). Teacher education and the development of professional identity: Learning to be a teacher. In P. Denicolo \& M. Kompf (Eds.), Connecting policy and practice: 
Challenges for teaching and learning in schools and universities (pp. 5-21). Oxford: Routledge.

Sen, A. (2009). Introduction. In The Pratichi education report II: Primary education in West Bengal changes and challenges (pp. 9-18). Delhi: Pratichi (India) Trust.

Smith, D. E. (2005). Institutional ethnography: A sociology for people. Walnut Creek, CA: AltaMira Press.

Srivastava, P. (Ed.). (2013). Low-fee private schooling: Aggravating equity or mitigating disadvantage? Oxford: Symposium Books, Ltd..

Sujatha, K. (2014). Private tuition in India: Trends and issues, Revue Internationale d'éducation de Sèvres. Retrieved from: http://ries.revues.org/3796.

The Probe Team (1999). Public report on basic education in India. New Delhi: Oxford University Press.

Velaskar, P. (2010). Quality and inequality in Indian education: Some critical policy concerns. Contemporary Education Dialogue, 7(1), 58-93.

Wadhwa, W. (2013). Private inputs into schooling: Bang for the buck. Annual Status of Education Report. Retrieved from:

http://img.asercentre.org/docs/Publications/ASER\%20Reports/ASER_2013/ASER20

13_report\%20sections/willimawadhwaarticle.pdf

Zembylas, M. (2003). Interrogating “teacher identity”: Emotion, resistance, and selfformation. Educational Theory, 53(1), 107-127.

Zhang, W. (2014). The demand for shadow education in China: Mainstream teachers and power relations. Asia Pacific Journal of Education, 34(4), 436-454. 
Zhang, W., \& Bray, M. (2017). Micro-neoliberalism in China: Public-private interactions at the confluence of mainstream and shadow education. Journal of Education Policy, $32(1), 63-81$. 